\title{
Virtual Qur’ān: Authenticity, Authority, and Ayat in Bytes
}

\begin{abstract}
All seats in the women's wagon were taken when I got in at Tahrir Square. The stream of in-flowing bodies steered me to the corner where a young woman was sitting with an open mobile phone in her hand. The bright screen displayed lines of ayat ${ }^{1}$ - the Qur'ānic verses. Every now and then, she slid her finger over the glass "turning the pages over.” Not so long ago the same young woman would have been holding a small paper copy of the Qur'ānic book. Now, to see her gazing at the lit phone screen was nothing out of ordinary.

"I know it's a strange question," I addressed her, "but why do you like reading the Qur’ān on your mobile?”

She looked up at me with a slight surprise.

"Oh, it's just a matter of convenience," she replied, "and I can read it without ablutions even when I have my period.” Then, she promptly returned to looking silently at the screen.
\end{abstract}

This ethnographic vignette of a chance encounter over a mobile phone in a metro can be read in a number of ways. First of all, it serves as an overture to my account of the modes in which digital technology participates in shaping religious practice surrounding the Muslim sacred text in Egypt. Furthermore, it demonstrates that although over the past ten years or so the Qur'ānic message has been increasingly mediated by digital bytes and electronic devices, this mediation should not be perceived as "dematerialization" of the religious text. On the contrary, more and more popular "electronic Holy Qur'āns" still have material bodies that are capable of producing very tangible effects: the new forms of engagement with the Qur'ānic text, the debates over authenticity and textual authority, the realignments of religious tradition, and the constant efforts to create even better virtual Qur'āns. Additionally, by referencing female biology, the vignette reveals gender distinctions in the ways Qur'ānic software technology can be appropriated and applied by Muslim practitioners. Finally, it tacitly points to the link between books and other digital devices that mediate the Qur'ānic text.

\section{The mushaf and the Qur'ān}

Many of the practices and conversations surrounding digital copies of the Qur'ānic text are tied to a religious dogma which states that the Qur'ān is a vocally transmitted

1 All translations from Arabic included in this essay are mine.

Ә Open Access. (C) 2020 Natalia Suit, published by De Gruyter. @) BY-NC-ND This work is licensed under a Creative Commons Attribution-NonCommercial-NoDerivatives 4.0 International License.

https://doi.org/10.1515/9783110634440-012 
revelation. Etymologically, the word Qur'ān is derived from the root word qara'a that refers to "reading” or "reciting." More precisely, Qur'ān means "the spoken message of Allah." This emphasis on vocal mediation is grounded in the teachings of the Prophet Muhammad himself, who encouraged his companions to memorize and recite the message he received through spoken words. "Chant it, for whoever does not chant it is not one of us," says the Prophet in a well-known hadith (account of the deeds and words of the Prophet Muhammad) narrated by Ibn Kathir. ${ }^{2}$ There are many accounts like this in addition to verses in the Qur'ān itself that remind Muslims about the importance of recitation, resulting in a long and rich tradition of the art of Qurānic chanting that continues to be an important part of the religious education in Egypt and other parts of the Muslim world.

But the Qur'ān is not only mediated by voice. It has also had a less evanescent medium in the form of a book - consisting of pages, binding, and script - that is called a mushaf (read with "s" and "h" pronounced separately). The word mushaf comes from the root suhuf (bound pages) and is primarily understood to refer to the pages that carry the text of the Qur'ān. It is not mentioned in the Qur'ān itself but appears later in scholarly writings about the Qur'ān. Grammatically, unlike the Quran, mushaf has a plural form masahif, indicating an essential difference between the ontological status of the two. One is divine; the other is not. Despite the fact that reporters covering the memorable Burn-the-Qur'ān Day often used the word Qur'ān in plural - "the Qur'āns" (as it is customarily done with the Bible, where a proper noun denotes both the content and the object that carries it) - in Arabic the word Qur'ān does not have a plural form. There is only one Qur'ān al-Qur'ān, the Qur'ān - mediated by a man-made book, a mushaf.

In spite of the emphasis on vocal mediation of the message, Muslims have not neglected the corporeal medium of the Qur'ān, whether to beautify it through calligraphy, or to address it through acts of ritual purity, or to treat it with particular forms of deference. Given the persistent presence of the Qur'ānic book in Muslim religious practice (with millions of its copies being printed now every year in the Middle East alone), it is hard to think of the Qur'ān only in terms of its abstract, ethereal message without addressing the presence of its tangible "carrier."

By looking at the Qur'ānic book - not through it - and paying attention to its manufacturing, material form, and practical use, I am able to not only track the forms of mediation taking place between the actual object, script, and the message, but also to understand challenges engendered by the new digital technology and the consequences of its use for religious practice. Thus, speaking

2 Abu al-Fada' Isma‘il Ibn 'Amr Ibn Kathir, Tafsir al-Qur'ān al-'Azim, vol. 7 (Beirut: Dar al-Fikr, 1966), 481. 
about virtual Qur'ān necessarily entails speaking about the Qur'ān in print. Moreover, it is one of the underlying theoretical suppositions of this essay that these two forms of mediation of the Qur'ānic text should be treated as enfolded in each other rather than simply in terms of older technology being replaced by newer forms.

The complexity of the process of technological mediation has already been pointed out by Marshall McLuhan who saw technology - and printed books among them - as multilayered environments in which multiple media, like Russian Matrioshkas, "nest” in each other. "The 'content' of any medium is always another medium," 3 proposed McLuhan, seeing speech mediated by script used in printing and reproduced through books as an example of such a conglomeration of media, each of which had the ability to introduce change into human affairs through its process of mediation. However, as W.J.T. Mitchell has reminded us, we should not see this "nesting" phenomenon as a historical sequence. ${ }^{4}$ From a perspective of the book history, the juxtaposition of printed and electronic copies of the Qur'ān highlights the overlapping nature of different forms of text mediation. As much as handwriting did not end with the introduction of printing so digitization does not entirely eclipse presswork. Computers may have produced new forms of text consumption and reshaped the meaning of printing as a dominant type of text reproduction, but the appearance of one medium rarely completely eliminated the older ones. For instance, almost a century of coexistence between the two ways in which the Qur'ānic text was rendered spans the time from the first local print productions in Egypt to the decline of the manuscript economy. ${ }^{5}$ During that time both media had an effect on each other, transforming each other's forms and meanings. Similarly, both printed and digital versions of the Qur'ān are nowadays available on the religious market and the growing numbers of both underlie diversification of their users, including generational, economic, aesthetic, or educational differences. And, as in the past, the digitized text of the Qur'ān is in many ways affected by its predecessor - the book. So, overemphasizing the chronology may prevent us from noticing how the older media can become incorporated into the newer ones and vice versa. ${ }^{6}$ And therefore, I do

3 Marshall McLuhan, Understanding Media: The Extensions of Man (New York: The New American Library, 1964), 23.

4 W.J.T. Mitchell, “There Are No Visual Media,” Journal of Visual Culture 4/2 (2005): 262.

5 Kathryn Schwartz, Meaningful Mediums: A Material and Intellectual History of Manuscript and Print Production in the Nineteenth-Century Ottoman Cairo (Ph.D. diss., Harvard University, 2015). 6 Brinckley Messick makes the same argument in relation to writing and print. Brinkley Messick, The Calligraphic State: Textual Domination and History in a Muslim Society (Berkley: University of California Press, 1993). 
not separate the forms in which the Qur'anic text is stabilized by printing (and the practices produced by the materiality of a printed book) from the practices and materialities engender by the digital technology.

\section{2 “Etiquette" of the Qur'ānic Book}

A quick search online for the word "Qur'ān" shows that in popular English, the Qur'ān is often referred to as the Muslim “holy book” or “Holy Qur'ān.” Yet strictly speaking, and as we already know, it is not a book. Nor is it "holy" in the common understanding of this word. Neither the book nor the message are "holy" in the way the Bible is referred to in the Christian tradition. In the Arabic language, the word muqaddas (holy) and its derivatives do not index the Qur'ān or its tangible body. Perhaps it is because al-kitab al-muqaddas - the "holy book" - is the phrase already reserved by the Arabic speaking Christians to describe their own scripture, the Bible. Muslims in Egypt never speak of the Qur'ān or mushaf's holiness but instead always emphasized the notion of "deference" (ihtiram) which should be directed towards the book that carries the text of the Qur'ān. The word ihtiram comes from the root harima "to be prohibited, to be forbidden, to exclude or withhold, which in some of its derivative verbal forms has the connotation of being set aside or inviolable. But, etymology alone does not help to understand the realities of the mushaf and the Qur'ān. Rather than relying solely on the word's semantic field, I suggest we turn to the actual practices of ihtiram performed by Qur'ānic users, people who read and handle Qur'ānic copies in the course of daily activities, and to think of them as meaning-making enactments ${ }^{7}$ of the Qur'ān expressed through the daily routines of worship and piety known as the etiquette of the mushaf or adab al-mushaf.

These practices are inseparably entangled with the materiality of the object that mediates the text. Objects do not simply "carry” the Qur'ānic text. They mediate it, which means that they change the ways in which people perceive the meaning of the text and the practices that surround it, changing themselves in the process. A book made of paper is not the same as the Quranic text on the screen of a phone. A text visible on the page does not necessarily appear in the same way as its digitized version under a plastic cover. When the medium of the message changes, the etiquette of the electronic "mushaf" changes as well, and practices of ihtiram are redefined to accommodate this

7 Annemarie Mol, The Body Multiple: Ontology in Medical Practice (Durham: Duke University Press, 2002), 31-33. 
new and unprecedented materiality of the text. I will return to this issue, but in order to grasp the challenges of the co-presence of a new medium, I need to briefly describe the forms of rapport long established between the practitioners and their printed masahif.

What practitioners know about adab al-mushaf comes from lessons at the mosque, education at home, mass media, and self-study, and pertains to multiple situations in the course of daily activities. Over time, I trained myself to pay attention to the small gestures of deference that surrounded the mushaf in private and public spaces. I learned to notice that a mushaf was not left open turned upside down, was not covered with other books and objects, was not left on the floor or on a table with food. I watched these acts of deferment implemented daily through gestures of ihtiram, I saw my friends and strangers uncover a mushaf, pick it up, move it, put it away; I learned where and when it could be left undisturbed, at least as much as life in crowded and polluted spaces allowed. In the discussions about the Qur'ān, I was given many examples of what not to do with the mushaf: I was warned not to wet my finger with my saliva when turning the pages; not to read it in bed; not to sit, sleep, or lean upon a mushaf; not to throw it; not to put anything between its pages except empty sheets of paper; and not to scribble notes on it. Sometimes ordinary acts of respect would take me by surprise or frustrate me. I remember the moment of awkwardness when my friend Rahab's mother conspicuously removed a pair of golden earrings I accidentally put on her mushaf. I also remember incidents in one of the libraries, where an anonymous stranger would persistently remove a mushaf from the lower shelf where its call number would require it to be to the top shelf, out of cataloging order.

Although the rules of adab al-mushaf are quite clear and specific, even classical scholars recognized the difficulty of following the rules of purity in all circumstances and at all times. A well-known example is the case of pupils in the Qur'ānic schools who, if the rules were upheld, would have to perform ablutions after every urination or defecation, which would disrupt the class and take too much time away from instruction. Therefore different provisions and exceptions, such as holding or touching the book with other objects or between the outer parts of one's palms, have been made to reconcile the rules of purity with the daily exigencies. These provisions and exceptions have become incorporated into daily routines, and are even more necessary as transmigratory life in Cairo makes following the rules more cumbersome: for instance, the long hours of commuting to work could be spent on reading the Quran but making the required wudu' (ablutions) beforehand is not always possible. It is, therefore, left to the conscience of individual practitioners how to reconcile adab al-mushaf with the contingencies of rapidly changing and accelerated urban lifestyle. 
Friendships too may make relationships with some objects more complicated, forcing the practitioners to make uneasy choices about whether their allegiances lie with people or things. I know I was at times the cause of such dilemmas. When some years ago, I traveled for the first time with Rahab's family to their cabin on the shores of Marsa Matruh, I was not yet aware of the rules that guided the handling of a mushaf. At the end of the day, I sat on a comfortable bed and stretched lazily, not being able to decide whether I was too tired to read anything. Out of the corner of my eye I saw a book on the bedside table and picked it up. It was a mushaf. I flipped through the pages absentmindedly. Rahab walked into the room and saw the book in my hands. "Do you mind putting it away?" she said with unease, "you are ... you know ... your hands are not clean." "I just washed them," I said. "That's not it." She was clearly struggling. "You are ... you are not Muslim so ... you shouldn't touch it." Rahab did not want me to hold the mushaf. But because we were friends, she could openly ask me to put it away, although it was not a comfortable request to make. In my interactions with other people, I occasionally saw a fleeting hesitation and an almost instinctive jerk of the hand in a protective gesture when I reached for a mushaf. Once or twice it was silently removed from my hands with a quick, but telling motion.

Yet, Rahab was one of few who candidly referred to my impurity. As nonMuslim, I could never be in a state of tahara, but neither was Rahab that evening in Marsa Matruh. At her request, I put the mushaf down. She immediately picked up two other books from the coffee table and using them as tongs carried the mushaf out of the room. "I'm having my period," she said in a matter-of-fact voice, responding to the surprised look I threw at her contraption. By not touching the Qur'ānic text while menstruating, Rahab followed the rules of handling the mushaf habituated by generations of Muslim women. These rules today are taught in a variety of venues, including increasingly popular in Egypt religious websites containing fatawa (religious judiciary opinions), such as the one belonging to the al-Azhar university, an important Egyptian religious institution. Under the keywords: menstruating women and reading the Qur'ān there is a following fatwa:

Question: What is the ruling on menstruating woman entering the women's prayer room in a mosque to participate in studying and memorizing the Qur'änic verses, memorizing the Qur'ān [in general], and touching the Qur'ān during this period?

Answer: Prof. Dr. 'Ali Goma'a [who served as Grand Mufti of Egypt between 2003-2013]

It is not permissible for a menstruating woman to enter the mosque for any purpose other than passing, because the Prophet (peace and blessings of Allah be upon him) said: "I do not permit a menstruating or impure person to enter the mosque," narrated by Abu Dawood. 
It is not permissible for a menstruating woman to touch the mushaf or to read the Qur'ann. However, the Maliki [school of law] permitts the woman to read a little of the Qur'ān without touching the mushaf, so that she does not forget it. ${ }^{8}$

This is a well-known guideline; nonetheless, not all women take for granted this particular bodily comportment with the Qur'ānic book, as prescribed by the predominant legal schools (madhab) in Egypt. The piety movement that has grown in the last two decades among Egyptian women has produced female practitioners who want to learn more about their religion. ${ }^{9}$ By rejecting modern and secular values promoted by the Egyptian government, and trying to oppose various social pressures, they turn to religion for empowerment. These women choose to submit to Islamic principles with diligence and conscious decision-making, including judgements about what to do and what to avoid in time of menstruation.

Apart from indicating various levels of religiosity, the reactions of my female friends and acquaintances to the issue of touching a mushaf during periodic bleeding indicate modern shifts in the attitudes towards one's own body. Some women, like Rahab, consider menstruation as a state of major impurity and simply accept the ruling that in that state they cannot physically read the Qur'ān. Others are unsure about how to think of their own menstruating bodies, perceiving the prohibition not so much a matter of ritual uncleanliness, but rather a part of general convention that should, nevertheless, be upheld. Some women, conveying that a prohibition of touching the book makes them feel somehow "dirty," question the rationale behind this practice, but still follow the guidelines. And a few, like Dalia, consider menstruation a biological function that should not prohibit a pious woman like herself from cultivating - as she described it - a personal relationship with Allah, including holding the words of the message mediated in a tangible way by a mushaf without any restrictions. Regardless of their convictions, with the introduction of new technologies (radio, TV, audio tapes, CDs) women in Egypt have been finding creative ways to negotiate the rules separating them from the Qur'ānic message. However, the advent of the Qur'ānic

8 "Reading of the Qur'ān, handling the mushaf, and entering the mosque in a state of menstruation." Fatwa no. 406 issued on the 2nd of March, 2005, by Professor 'Ali Goma'a. Website of Dar al-Ifta' at al-Azhar University. http://www.dar-alifta.org/AR/ViewFatwa.aspx?sec=fatwa\&ID=11392. See also: "Reading of the Qur'ān and handling the mushaf in a state of menstruation.” Fatwa no. 2841 issued on the 11th of May, 2016, no author. Website of Dar al-Ifta' at al-Azhar University. http://www.dar-alifta.org/AR/ViewFatwa.aspx?sec=fatwa\&ID=12343.

9 Saba Mahmood, Politics of Piety: The Islamic Revival and the Feminist Subject (Princeton, N.J.: Princeton University Press, 2012). 
phone and tablet applications has opened up for them a whole new way to access the Qur'ān without transgressing the rules of adab al-mushaf.

My attention to the corporeal presence of the book articulated so far through this ethnographic material should by no means suggest that the Islamic legal pronouncements standing behind the rules of $a d a b$ al-mushaf assign any priority to the book over the Qur'anic message. Yet the same pronouncements about the etiquette of the Qur'annic book attest to the fact that it is very hard to demarcate a clear boundary between the intangible, eternal words of Allah and their material mediators in the form of perishable ink, paint, paper, and script. On a practical level, this complicated relation between the message and its conveyers becomes most obvious when the medium that conveys the message is drastically changed. The introduction of digital technologies in the dissemination of the Qur'ān provides us with an opportunity to ask: how does a change in medium circumscribe the message? In other words, how does one enact a "digital Qur'ān" according to the rules of adab al-mushaf and what are the results of this enactment?

\section{Virtual Qur’ān}

The co-presence of the print and the digital has offered new possibilities for transmission of the Qur'ānic text and has produced alternative understandings of interaction between script and its digital medium. It has also engendered a critical change in the ways practitioners perceive Qur'ānic text as an integral part of the mushaf. The "virtual Qur'ān" is not a book in the ordinary sense of this word at all. It is a text mediated by the screen of a computer, an electronic device, or a mobile phone, where it shares memory space with other texts and images. An electronic device, especially a mobile phone, can hardly be called a mushaf (although on a few rare occasions, I have seen this word being applied in web advertisements). Moreover, electronic devices that mediate digital Qur'ān assume many forms and types: from small, portable, and multifunctional cell phones and tablets, uni-purpose walk-man like mini-players, or pen-like reading devices designed specifically for learning how to recite for non-Arabic speaking Muslims, to laptops and stationary computers with touch screens and CD and DVD players that can display the Qur’ān interactively. ${ }^{10}$

10 The electronic Qur'ānic media - like video and audiotapes circulating on the religious market - also affects the shaping of the Egyptian public sphere and their practices of ethical 
The Qur'ānic applications used on phones and tablets are designed mainly for reading and listening. The more specialized software allows not only to read and listen, but also to search for particular words, verses, or exegetic explanations. It may contain a dictionary, translations into other languages and guidelines facilitating proper recitation. Some programs include an option of following the text while listening to one's favorite qari - a Qur'ānic reciter. These versatile types of software (in terms of their use) are increasingly popular not only with the University of al-Azhar students, but also with younger Muslims who are interested in studying the Qur'ānic text on their own as a form of piety. The specialized devices containing exclusively the Qur'ānic text are becoming more popular as well, but they are rather expensive on the Egyptian market and the average, middle-class Muslims cannot afford them. The phone applications are by far most accessible, thus constituting the most popular form of digitized Qur'ān in Egypt. They are available for free or for a moderate fee from various websites and Islamic organizations, but they offer a less diversified range of functions. However, because the number of smart phones in Egypt has been steadily rising, reaching at this point about twenty-seven million users, mobiles have become the most popular platform for the display of the Qur'ānic text. ${ }^{11}$

Each of the electronic devices mediates the Qur'ānic text in particular ways and elicits different forms of engagement with the message. The "PenMan Holy Qur’ān” or “Iqra'a Digital Qur'ān” - Korean-made devices which are advertised and available on the Egyptian market - are, perhaps, the most versatile devices in terms of their content, portability, and application. Because of their convenient size, they can be read and listened to in various locations and circumstances. They feature exegetic explanations, tools for memorization (such as automatic repetition of marked passages or different speeds of recitation), and various search options. The most sophisticated ones show qibla (the direction of prayer), play the call to prayer at the right times, and include extra supplications and prayers. They also come with extra memory, allowing users to store pictures, create recordings, and convert files. There is even a radio option in some of the newer models. They are advertised as "the best gift for a Muslim learner who wants to study the Qur'ān.”

The specialized software available for computers is specifically design for textual study and requires a beyond-common knowledge of the Qur'ānic text, its grammar, orthography, and schools of recitations. Reading the Qur'ān in such

self-improvement. Charles Hirschkind, The Ethical Soundscape: Cassette Sermons and Islamic Counterpublics (New York: Columbia University Press, 2006).

11 "Number of smartphone users in Egypt from 2013 to 2019 (in millions)." Statista: the Statistics Portal. https://www.statista.com/statistics/467747/forecast-of-smartphone-users-in-egypt/ 
specialized software presupposes an academic engagement with the text that entails pausing, rereading, and analysing the content, and the emphasis on the "immersion" in the text through sound and vision is not a priority. The applications used on mobile phones, on the other hand, are more likely to promote reading for "immersion" - a form of reading that emphasizes the sound without necessarily pausing to analyse the content. I suggest that we call this form of engagement with the Qur'ānic text an affectual reading - reading that is likely to illicit an emotional response from the reader. It is often connected with the movement of the reader's lips and silent or half-silent recitation that allows the reader to access the text visually and aurally in a way that more fully engages the senses.

Thus, various forms of devices - laptops, "PenMan Digital Qur’āns," tablets, or phones - engender new ways of thinking about the Qur'ānic text by creating a challenge to the traditional forms of adab al-mușhaf. The gamut of most common questions that highlight the need to revisit the rules of the Qur'annic etiquette in relation to the new technology include a number of technology-related concerns. These following examples come from fatwa websites easily accessible in Egypt (like the one belonging to al-Azhar University) where Muslim practitioners can ask questions about any religious legal guidelines and rules, such as:

- Is it permissible to use a digital version of the Qur'ān?

- Are you supposed to perform wudu (full ablutions) to read the Qur'ān online or a digital Qur'ān?

- Is it allowed to listen to the Qur'ān in the digital format (on laptop, mobile, or mp3's form) without wudu?

- Is it allowed in Islam to load the Qur'ān into a smart phone as pdf or in an audio format?

- Can I touch or keep the smart phone in my pocket if the Qur'ān is loaded in it as pdf or in an audio format when I don't have wudu?

- How can I determine whether or not a mobile phone background image is appropriate if my phone has the Qur'ān in it?

- Is deleting a "Qur'ān.pdf" destroying a copy of the Qur'ān?

- Is it allowed to enter the bathroom when I have the smart phone in my pocket where the Qur'ān is loaded as pdf or audio format?

The examples above constitute a set of most ubiquitous questions related to the digitized Qur'ān and pop up time and again in different online discussions and private conversations. The last question in particular is an interesting case, as it evoked significant discussion when the first Qur'ānic phone apps appeared on the market. The initial opinions regarding how to act towards an electronic copy 
of the Qur'ānic text in ritually unclean places - such as bathrooms - were not unanimous. A few scholars insisted that in those places the rules of adab should apply in the same way to both objects, the book and the phone alike; others followed the argumentation implied by a well-known anecdotic fatwa also circulating the Internet:

A man asked a sheikh whether it was permitted to bring a mobile phone with the Qur'ānic verses to the bathroom. The sheikh answered, "It is permissible because the verses are in the memory of the phone."

The man asked again, "But sheikh, we are talking about the Qur'ānic verses and the most beautiful names of Allah, and you are saying that it is permitted to take them to the bathroom?” The sheikh replied, “Have you memorized any verses from the Qur'ān?”

"Yes," said the man.

"Well then," retorted the sheikh, "when you go to the bathroom, leave your head by the door and then step in.

Even though a mushaf, an actual physical book, should not be brought to the bathroom - and I have seen instances when people removed their copies from bags or pockets before entering such a place - having the Qur'ān on a phone does not call for the same precautions. Yet, although scholars admit that it would be unreasonable to expect people to leave their phones outside the bathroom unlike inexpensive masahif, they could be easily stolen - they surround the permission to bring the digitized Qur'ān to the bathroom with a stipulation: the sound should be switched off and the verses of the Qur'ān should not appear on the screen.

Menstruating women have deployed this interpretation of adab al-mushaf in relation to the use of new technology. Since mobile phones and tablets on which the Qur'ān is recorded do not come under the same rules as the mushaf, this also means that other rules of purity do not apply in the same way either. The rationale behind both is that the letters of the Qur'ān in these devices are "different" than the letters in the mushaf. Thus, menstruating women follow opinions expressed by the sheikhs of al-Azhar that an electronic device constitutes merely a carrier and a barrier for the text. The plastic case or glass screen is a safe barrier, as it cannot be traversed: one cannot directly touch the digital letters, as they - instead of being "fixed" on the page - appear and disappear from display. For that reason, legally menstruation has no effect on the practical use of the Quranic text in a digital device because, from this point of view, digital letters are immaterial.

This opinion has been disseminated not only by fatwa websites, but also by electronic women's periodicals and news web portals, such as the popular Masrawy that published in 2016 a fatwa by the Grand Mufti Dr. Ahmad al-Tayeb: 
Question: Is it permissible for a menstruating woman to read the Qur'ān from any source other than the mushaf?

Dr. Ahmad al-Tayeb, Sheikh of Al-Azhar, replies: Imam Malik allowed the reading of the Qur'ān without touching the mushaf during the menstrual cycle, so that the inability to read does not lead to forgetting the Qur'ān.

Based on this, it is permissible for a menstruating woman to read the Qur'ān from any source other than the mushaf in order to be rewarded [with blessings], even if it is daily. It is known what the answer is to the question, if the case is as stated. And God Almighty knows best. ${ }^{12}$

A fatwa on this subject which featured on the al-Azhar website is more ambiguous and indicates that the difference between the mushaf and an electronic device is still somewhat debatable. The fatwa reminds practitioners that every letter read from the Qur'ān brings the reader ten blessings. This applies to the letters read on the electronic screens as well, even if the reader has not performed the ablution (wudu) - with a few exceptions, including menstruation. However, says the same fatwa, reading from the mushaf - a paper book - is better than reading from an electronic device and touching the Qur'ānic text on an electronic screen is not the same as touching the mushaf because the text on a screen appears there as on a surface of water or a mirror. The purity required for touching the mushaf is not obligatory in this case because touching the screen is like touching the Qur'ān's shadow. In the conclusion, the fatwa states that reading from the mushaf engages the touch and eye more than reading from the phone. ${ }^{13}$ The equivocality of this pronouncement leaves some leeway to treat the phone differently which, in consequence, allows for a common conviction expressed by the woman I approached on the metro.

12 "Is it correct for a menstruating person to read the Qur'ān from a source other than a mushaf?" (Hal yusihh lil ha'id an taqra' min ayy masdar ghir mushaf? Masrawy (16 January 2016); online at: http://www.masrawy.com. This article has been archived since then and is not accessible on the newspaper's website anymore. A note about websites: In Egypt, a lot of religious information is distributed on the Internet. I have used them as sources because they are often accessed by Egyptian practitioners via their phones. Some of those websites are more stable - like the website of Dar al-Ifta at al-Azhar of King Fahd Complex. Others, however, especially the newspaper sites, do not archive their articles beyond a certain period of time. For that reason, many of the articles published during my fieldwork in 2012 are not available online anymore. Yet, their ephemerality does not mean, in my opinion, that they should be excluded as legitimate ethnographic sources, as they have become a common means of religious education among younger and middle-age Egyptians. 13 "Benefits of reading the Qur'ān from an electronic screen." Fatwa no. 3668 issued on the 14th of December, 2016, no author. Website of Dar al-Ifta' at al-Azhar University. http://www.daralifta.org/AR/ViewFatwa. aspx?sec=fatwa\&ID=13248. 


\section{Digitizing Qur’ānic Orthography}

The attempts to reproduce the Qur'ānic text online have been taking place for about two decades now. Yet, only within the last ten years or so have the software companies and app developers begun to offer electronic editions of the Qur'ān in Arabic (English translations have been available in electronic form since mid-to late 1990s). Interestingly, it is the technology itself that for a long period happened to be the obstacle to spreading the virtual Qur'ān. In spite of growing interest in digitization of the Qur'ānic text, boosted by the quick spread of new technology, skills, and digitally encoded Arabic fonts in the Muslim world, rendering the Qur'ān in a digital format presented numerous conundrums for programmers and religious authorities alike. Although practitioners with access to computers and other electronic devices saw benefits of using the digitized Qur'ān, it was the programmers' inability to properly reproduce the Qur'ānic text in an electronic format that impaired its spread online.

First of all, the calligraphic styles used over the centuries for writing masahif and reproduced through lithographic and offset printing - that facilitated continuation of many calligraphic traditions in mechanically reproduced texts of the Qur'ān - have produced their own regimes of authority and authentication that were hard to recreate through a font style that did not participate in the tradition of Qur'ānic calligraphy. It is particularly true when we consider how the introduction of typographic print in Egypt disrupted the semantic system of distinct calligraphic styles and their fields of signification by visually unifying texts belonging to different spheres of religious, political and economic practice. With the introduction of printing, a variety of calligraphic styles that communicated different contents were replaced by one uniform printing font that lost its capacity to convey meaning through format. Eventually, Qur'āniclike typefaces emerged in printing as well, representing their own distinctive visual styles that in many ways was much more grounded in the pre-print scripts than in the then-contemporary secular printing styles, full of innovative "nonQur'ānic” designs.

When digitization entered Qur'ānic printing and dissemination markets in Egypt at the beginning of the nineties, this technology was initially able to preserve the Qur'ānic calligraphic tradition only by reproducing handwritten or printed masahif as uneditable, undividable text blocks or pictures in which fragments of text could not be copied or searched. Although letters of the Arabic alphabet were encoded first in ASCII (the American Standard Code for Information Interchange ASCII) and later in ISO International Standards Organization, they were significantly simplified and the codification did not include any of the additional layers of the Arabic script, including a number of diacritics. A 
number of bigger corporation (like IBM, for instance) addressed this inadequacy by creating separate encoding systems that represented non-Latin scripts in a more correct way, but the texts written in those coding systems were not easily transferable from one digital environment to another without causing distortion of the text. These distortions included placement of diacritic marks over incorrect letters which changed the meaning of the words. This was, of course, especially problematic for transferring the Quraanic text. From this perspective, the ease of transferring text from one format to another, or from one electronic device to another was, ironically, one of the biggest predicaments of dissemination for the digitized Qur'ān. The challenge, then, was to create a program in which the Qurānic text would be stable enough, yet editable, not easily manipulated but transferable.

By the end of the twentieth century, the Unicode system emerged as an answer to the confusion. Its major advantage was that it helped to include many more variations of the Arabic letters and a much larger number of diacritics. ${ }^{14}$ However, the basis of the digital revolution, the Unicode system used worldwide for encoding texts in different writing systems was, nevertheless, grounded in a typographic, Latin-script based tradition of assigning a particular code to a particular letter in a sequential order. Although finally good enough to represent the contemporary Arabic script, this system still did not support all the variants and diacritics needed to create the Qur'ānic text.

Moreover, by that point, changes in religious visual culture had begun to take place. These were prompted in particular by Qur'ānic printed editions popular in Egypt, such as Mushaf Fu'ad or Mushaf al-Shimarly, and in general by the modern aesthetics of the secular texts to which the readers became already accustomed. The reading habits of Muslim practitioners had already changed. People desired to read the text of the Qur'ān that was "legible" and "print-like," and they wanted it to be user-friendly like other easily accessible and usable non-religious electronic texts. Therefore, the push to digitize the Qur'ān in Egypt did not come at first from institutions, such as al-Azhar, but through the initiatives of individual practitioners who were interested in both the correct spelling/diacritics and usability of the text. The early attempts to create searchable digitized texts of the Qur'ān were undertaken by computer engineers and programmers, which, in return, prompted religious authorities to step in.

One of the first programs that would allow searching, copying, and pasting the Quranic text without distortion of the position of the letters, or changing them

14 J.R. Osborn, Letters of Light: Arabic Script in Calligraphy, Print, and Digital Design (Cambridge: Harvard University Press, 2017), 170. 
into numeric signs and symbols, was created at the King Fahd Quran Complex. ${ }^{15}$ Its team of engineers has recently released to the public domain a font application that is also compatible with Unicode. The Qur'ānic application is available for free on the Complex's website and has been developed specifically to accommodate the text of the Qur'ān. Also, a Dutch linguist and designer, Thomas Milo, and his company DecoType ${ }^{16}$ have been successful in developing new ways of encoding Arabic script strictly following the rules of Arabic calligraphy that allow preparing fully marked Qur'ānic text. They used this software to create the first digital Omani mushaf called Mushaf Muscat. ${ }^{17}$

However, the problem of orthographic distortion and control of the text still exists. In order to understand it, we need to understand two issues: the tradition of the Qur'ānic spelling and the ways in which the Qur'ānic text has been historically authenticated (isnad).

\section{How Does One Know that the Text is Correct? Authenticity and Authority}

The transition of the Qur'anic text from handwriting to print did not happen without controversies. One of the important objections at that time was informed by the problematic relation of printing to the past. The introduction of the printing press created an interruption in the chain of authority produced by generations of copiers who learned from their teachers. Before print, what authenticated the accuracy of the text and what gave the text its authority - whether written or recited - was the isnad, a method of transmission in which the provenience of a text was traced through a person-to-person, student-to-teacher connection. The introduction of printing interrupted the isnad of person-to person instruction. "Printing," writes Wilson, "unlike the calligraphy and writing, could not trace its origins back to the early Muslim community but rather to the fifteenthcentury Germany and to the non-Muslim printers who developed the technology. Therefore, printed books lacked a lineage that provided Islamic authenticity and guaranteed the quality of work." ${ }^{\prime 18}$ Printing was a technology of multiplicity and

15 Available online from The King Fahd Glorious Qur'ān Printing Complex at: https://www.qurancomplex.org.

16 Available online at the company's website: https://www.decotype.com/.

17 Mushaf available online at https://www.mushafmuscat.om/.

18 Brett Wilson, Translating the Qur'ān in an Age of Nationalism: Print Culture and Modern Islam in Turkey (Oxford: Oxford University Press, 2014), 40. 
assemblage. Each mushaf produced by a less or more accomplished copyist was nonetheless singular and unique, easily checked for accuracy and completeness, and easy to correct if any mistakes occurred in the process of writing. A printed mushaf could multiply the same shape of a letter or a space between words or, indeed, a misspelling - hundreds of times. A missed word in a handwritten mushaf - a rare event - was added in the margin of the text. A correction of an orthographic mistake was not difficult either. Correcting hundreds of copies carrying the same mistake defeated the benefits of fast multiplication. In this circumstance, the question of the text's correct spelling was crucial. How could the accuracy of a written text, previously secured by isnad, be preserved now? With printing as primary technology of dissemination, the orthographic mediation of the Qur'ānic message was at risk.

The problem of control over the typographic text has been solved in Egypt by the creation of institutional mechanisms to supervise the production and distribution of the Qur'ānic text. Al-Azhar's branch, the Islamic Research Council, is a parent institution to the Mushaf Committee (the full name of which is the "Committee for the Review of the Noble Mushaf"). ${ }^{19}$ The Committee includes a chair, two deputies, and over ten members. The Committee oversees all Qur'ānic production and distribution in Egypt by assigning permits to print and sell. Several stages are required to obtain a license. A publishing house must first submit a copy of the Qur'ānic text to be reproduced for inspection. Then ten test copies of printed text are requested. Once proofed and found correct, the Committee grants the house a permit to print. Several random copies of the Qur'ānic text are selected from the run and forwarded for further inspection. Once the house passes this inspection the Committee issues a license to sell the Qur'ānic book. In a private conversation, a calligraphy specialist employed by the publishing house al-Shimarli described the procedure of getting a license in similar terms, emphasizing that because of this rigorous method the house had received very little complaints from the readers about any misprints. ${ }^{20}$

Considering the complexity of the process of authentication for printed masahif, how can the problem of correctness be addressed in the Internet, where the circulation of the unlicensed text is possible? Moreover, how can the institutionalized forms of text control - like the procedures described above - be replicated on the digital level? The channels of bureaucratic control over the publishing houses have already been established, but similar ways of authentication are not yet available for the copies circulating the Internet. The most

19 Lagnat muraga'a al-mushaf al-sharif.

20 Private conversation on 16 May, 2012. 
pressing questions that emerge relate to the creation of a new form of isnad for electronic versions of the Qur'ān, to the protection of the integrity of the text in the process of transfer from one environment to another, and to the evaluation of existing copies for their accuracy. Two of the most influential Muslim institutions that deal with the Qur'ānic text - University of al-Azhar, Egypt, and King Fahd Complex for Printing the Holy Qur'ān, Saudi Arabia - addressed this challenge by creating their own digital versions of the Qur'ān that are available to download for free from their websites. However, their versions of the Qur'ān compete with those produced by small, for-profit companies attuned to the digital market who offer a broader range of design, functionality, and features. They are also able to upgrade their applications faster.

This discrepancy between the needs and expectations of the consumers of the Qur'ānic text (quick access to a user friendly application) and concerns of the religious authorities (how to control the text's production to make sure that the text follows the correct rules of orthography and design) creates a dynamic field of activities at the center of which lays the materiality of the Qur'ānic text. On the one hand, these activities include discussions between the al-Azhar authorities and the Egyptian parliament about the forms of legal power to penalize both the publishers and electronic and software companies that release the Qur'ānic copies that do not follow the standards prescribed by the al-Azhar. On the other hand, the flaws present in some of the software available in Egypt and beyond undermine in subtle ways the primacy of al-Azhar as a center of the Muslim authority and influence, slowly shifting the power to the Islamic Council in Saudi Arabia which has been quicker than al-Azhar in its efforts to produce a virtual Qur’ān.

\section{Conclusion}

One of the aims of this essay has been to explore how religious practice surrounding a religious text is rethought as a result of the introduction of new technology that mediates this text. I have outlined some of the differences in which the Qur'ān is enacted through the etiquette of the paper book and an electronic copy of the text. As a final point, I think it is important to ask what happens to the Qur'ān when its enactments start quite suddenly differing from the ones carried out by the previous generations of practitioners. Annemarie Mol, an anthropologist of practice, suggests that when we foreground the practices surrounding things we are able to track how those things come into being. If the socio-material practices differ, new things appear and the realities are multiplied. Instead of a passive 
thing in the middle seen from multiple perspectives we are faced with new things constantly coming into being. Yet the multiple objects do not fall apart, but as she puts it, they "tend to hang together somehow." ${ }^{21}$ For Muslim practitioners the Qur'ān in a phone that can be touched without ablutions is not suddenly different from the Qur'ān in a mushaf that cannot. This happens because practices that have ability to create new realities are always entangled with practices that stabilize things, give them a kind of inertia, and make them "hang together." However, the accelerating use of technology in accessing the Qur'ānic message begs a question: how much longer will the adab al-mushaf be relevant to the Qur'ān and when/if it ceases to be germane to Muslim practice, what will this change mean for the way the Qur'ān itself is understood and interpreted?

\section{Bibliography}

Hirschkind, Charles. The Ethical Soundscape: Cassette Sermons and Islamic Counterpublics. New York: Columbia University Press, 2006.

Ibn Kathir, Abu al-Fada' Isma ‘il Ibn ‘Amr. Tafsir al-Qur'ān al- ‘Azim. Vol. 7. Beirut: Dar al-Fikr, 1966.

Mahmood, Saba. Politics of Piety: The Islamic Revival and the Feminist Subject. Princeton, N.J.: Princeton University Press, 2012.

McLuhan, Marshall. Understanding Media: The Extensions of Man. New York: The New American Library, 1964.

Messick, Brinkley. The Calligraphic State: Textual Domination and History in a Muslim Society. Berkley: University of California Press, 1993.

Mitchell, W.J.T. “There Are No Visual Media.” Journal of Visual Culture 4/2 (2005): [full page numbers for article needed].

Mol, Annemarie. The Body Multiple: Ontology in Medical Practice. Durham: Duke University Press, 2002.

Osborn, J.R. Letters of Light: Arabic Script in Calligraphy, Print, and Digital Design. Cambridge: Harvard University Press, 2017.

Schwartz, Kathryn. Meaningful Mediums: A Material and Intellectual History of Manuscript and Print Production in the Nineteenth-Century Ottoman Cairo. Ph.D. diss., Harvard University, 2015.

Starrett, Gregory. Putting Islam to Work: Education, Politics, and Religious Transformation in Egypt. Berkley: University of California Press, 1998

Wilson, Brett. Translating the Qur'ān in an Age of Nationalism: Print Culture and Modern Islam in Turkey. Oxford: Oxford University Press, 2014.

21 Annemarie Mol, The Body Multiple: Ontology in Medical Practice (Durham: Duke University Press, 2002), 4-5. 